УДК:334.72:347.77

https://doi.org/10.35546/kntu2078-4481.2021.4.24

P.B. MOPO3OB

Херсонський державний аграрно-економічний університет ORCID: 0000-0002-1454-6296

О.Г. MOPO3OBA

Херсонський державний аграрно-економічний університет ORCID: 0000-0002-6501-3561

\title{
ДІАГНОСТИКА МЕРЕЖЕВОГО ПІДПРИЕМСТВА ЯК СПЕЦИФІЧНОЇ ФОРМИ ІНТЕЛЕКТУАЛЬНОГО БІЗНЕСУ
}

Головною метою дослідження є з'ясування напрямків діагностики мережевого підприємства. Визначення принципів діагностування, які полягають в підвалинах мережевого підприємства та за його межам. Системне узагальнення основних напрямків адаптації підприємства інтелектуального бізнесу до глобального простору та його взаємодію з іншими суб'єктами інформаційної економіки.

Досліджено особливості ринкової модифікації управління мережевими підприємствами та ряд практичних рекомендацій щзодо підвищення економічної ефективності на всіх рівнях господарювання.

Визначено роль діагностування, як джерела підвищення ефективності управління підприємствами на всіх рівнях функціонування в інтелектуальному бізнесі. Запропоновані теоретичні підходи щзодо особливостей ринкової модифікації управління підприсмствами, що можуть бути покладені в основу практичних рекомендацій щзоо налагодження їх ефективного функціонування.

Доведено, шео діагностування впливає на ефективність діяльності мережевих підприємств $i$ сприяє виходу із системної кризи економіки, в иілому. Сьогодні держава не може встановити повноцінний контроль над мережевими підприємствами, а підприємства не мають реальної економічної самостійності. Поетапний перехід до нової моделі взаємовідносин між державою $і$ підприємством включає: створення механізму виведення підприємств з застарілого економічного прочесу; створення рамкових умов, які будуть заохочувати до заснування нових мережевих підприсмств. Зменшень регламентачій, які протидіють даному прочесу; скасування пільг з боку держави для окремих галузей. Підвищення прозорості державної діяльності та інформаційної складової ринкових сигналів в інтелектуальному бізнесі, шляхом сприяння конкуренції на окремих інформаційних ринках. Запобігання зловживання ринком; поліпшення організаџії управління та контролю за мережевими підприємствами державними структурами та органами громадського контролю.

Запропоновані в досліджені теоретичні підходи до особливостей модифікації управління підприємств інтелектуального бізнесу можуть бути покладені в основу практичних рекомендацій щзодо налагодження їх ефективного функціонування в інформаційній економіці.

Ключові слова: діагностика, мережеве підприємство, інформація, ринкова модифікація, інтелектуальний бізнес, інформачійна економіка.

P.B. MOPO3OB

Херсонский государственный аграрно-экономический университет ORCID: 0000-0002-1454-6296

О.Г MOPO3OBA

Херсонский государственный аграрно-экономический университет ORCID: 0000-0002-6501-3561

\section{ДИАГНОСТИКА СЕТЕВОГО ПРЕДПРИЯТИЯ КАК СПЕЦИФИЧЕСКОЙ ФОРМЫ ИНТЕЛЛЕКТУАЛЬНОГО БИЗНЕСА}

Главной целью исследования является установление направлений диагностики сетевого предприятия. Определение принципов диагностирования, которые состоят в основах сетевого предприятия и за его пределами. Системное обобщение основных направлений адаптации предприятия интеллектуального бизнеса в глобальное пространство и его взаимодействие с другими субъектами информационной экономики.

Исследованы особенности рыночной модификации управления сетевыми предприятиями и ряд практических рекомендаций по повышению экономической эффективности на всех уровнях хозяйствования.

Определена роль диагностирования как источника повышения эффективности управления предприятиями на всех уровнях функиионирования в интеллектуальном бизнесе. Предложень теоретические подходы, касающиеся особенностей рыночной модификации управления предприятиями, 
которые могут быть положены в основу практических рекомендаций по налаживанию их эффективного функиионирования.

Доказано, что диагностирование влияет на эффективность деятельности сетевых предприятий и способствует выходу из системного кризиса экономики в целом. Сегодня государство не может установить полноценный контроль над сетевыми предприятиями, а у предприятий нет реальной экономической самостоятельности. Поэтапный переход $к$ новой модели взаимоотношений между государством и предприятием включает: создание механизма вывода предприятий из устаревшего экономического процесса; создание рамочных условий, которые будут поощрять создание новых сетевых предприятий.

Уменьшение регламентаций, противодействующих данному процессу; отмена льгот со стороны страны для отдельных отраслей. Повышение прозрачности государственной деятельности и информационной составляющей рыночных сигналов в интеллектуальном бизнесе путем содействия конкуренции на отдельных информащионных рынках. Предотвращчение злоупотребления рынком; улучшение организаџии управления и контроля над сетевыми предприятиями государственными структурами и органами общественного контроля.

Предложенные в исследованные теоретические подходы к особенностям модификации управления предприятий интеллектуального бизнеса могут быть положены в основу практических рекомендаций по налаживанию эффективного функиионирования в информационной экономике

Ключевые слова: диагностика, сетевое предприятие, информачия, рыночная модификация, интеллектуальный бизнес, информаџионная экономика.

R.V. MOROZOV

Kherson State Agrarian and Economic University ORCID: 0000-0002-1454-6296

O.G. MOROZOVA

Kherson State Agrarian and Economic University ORCID: 0000-0002-6501-3561

\section{DIAGNOSTICS OF A NETWORK ENTERPRISE AS A SPECIFIC FORMS OF INTELLECTUAL BUSINESS}

The main purpose of the study is to clarify the directions of diagnostics of the network enterprise. Defining the principles of diagnosis, which are the foundations of the network enterprise and beyond. Systematic generalization of the main directions of adaptation of the intellectual business enterprise to the global space and its interaction with other subjects of information economy.

Peculiarities of market modification of network enterprises management and a number of practical recommendations for improving economic efficiency at all levels of management are studied.

The role of diagnosing as a source of improving the efficiency of enterprise management at all levels of functioning in the intellectual business is identified. Theoretical approaches to the peculiarities of market modification of enterprise management are proposed, which can be used as a basis for practical recommendations for establishing their effective functioning.

Peculiarities of market modification of network enterprises management and a number of practical recommendations for improving economic efficiency at all levels of management are studied.

The role of diagnosing as a source of improving the efficiency of enterprise management at all levels of functioning in the intellectual business is identified. Theoretical approaches to the peculiarities of market modification of enterprise management are proposed, which can be used as a basis for practical recommendations for establishing their effective functioning. Reduction of regulations that oppose this process; abolition of state benefits for certain industries. Increasing the transparency of government activities and the information component of market signals in the intellectual business, by promoting competition in certain information markets. Prevention of market abuse; improving the organization of management and control over network enterprises by state structures and public control bodies.

The theoretical approaches to research features of modification of management of the enterprises of intellectual business offered in the researched can be put in a basis of practical recommendations on adjustment of their effective functioning in information economy.

Keywords: diagnostics, network enterprise, information, market modification, intellectual business, information economy.

\section{Постановка проблеми}

Теорія діагностування в інтелектуальному бізнесі мережевих підприємств в економіці виникла у 90-і роки XX ст. у зв'язку з розвитком інноваційних, новітніх технологій та потребою суспільства в інформації. На початку XXI століття суб’єкти підприємництва та економічні агенти все частіше 
стикаються з ситуацією, коли змінюється система цінностей суспільства, його соціальний розподіл, а причина тому - зміна місця і ролі інформації в сучасному мережевому господарстві де інформація набуває засобу досягнення соціального і економічного ефекту. Роль інформації в інтелектуальному бізнесі зростає, випереджуючи значимість засобів виробництва і природних ресурсів [1]. Використання інформаційних ресурсів забезпечує зростання ефективності в діагностуванні виробництва та збільшення суспільного продукту в інтелектуальному бізнесі. У структурі мережевого суспільного виробництва збільшується питома вага інтелектуально-технологічного сектору, у складі виробленої продукції зростає частка доданої вартості за рахунок інтелектуальної складової, змінюється характер людської праці на користь творчої та інтелектуальної діяльності.

\section{Аналіз останніх досліджень і публікацій}

Теоретико-методологічним, методичним та практичним аспектам поняття діагностування мережевого підприємства в інтелектуальному бізнесі розглядається видатними зарубіжними вченими, такими як: Л. Абалкін, Д .Белл, Е. Маймінас, Ж. Сапір, Дж. Стігліц, А. Тіхонов, Е. Тоффлер, Ю. Ясінський, Хаяші та ін. Серед визначних вітчизняних науковців треба відзначити: Т. Артьомову, В. Гейця, А. Гриценко, А. Чухно, Л. Федулову. Проте незважаючи на велику кількість досліджень проблеми мережевого підприємства в інтелектуальному бізнесі як середовища господарської діяльності фірми ще не $\epsilon$ чітко сформульованим і тому проблема потребує додаткового вивчення.

\section{Формулювання мети досліджень}

Метою статті є з'ясування новітніх методів діагностування та напрямків господарської діяльності мережевого підприємства; визначення принципів які полягають в основах діяльності мережевого підприємства та за його межами; визначити системне узагальнення основних напрямків адаптації мережевого підприємства та його взаємодія з іншими суб'єктами інтелектуального бізнесу в умовах інформаційної економіки

Зміст категорії діагностування мережевого підприємства в інтелектуальному бізнесі розглядається вченими як перехід від суспільства матеріальної продукції до його сервізації, розкриває роль і значення інформації, науки та освіти, аналізує значення людини, розвиток їі як особистості, розвиток демократії суспільства та удосконалення політичних систем, розвиток державного регулювання та прогнозування економіки, культури та інших сфер людської діяльності [1].

Термін «діагностика» в перекладі з грецької мови трактується як розпізнавання стану об’єкта за прямими та непрямими ознаками. Діагностика мережевого підприємства характеризується як аналіз та систематизована оцінка основних напрямків діяльності підприємства (інформаційного, економічного, виробничо-технічного та організаційного), яка проводиться для вивчення поточного стану підприємства та виявлення внутрішніх резервів, що можуть бути націлені на його подальший розвиток. Результатом діагностування є висновки про доцільність прийняття певних управлінських рішень щодо вирішення наявних на підприємстві проблем. Інформаційна база економічного діагностування $є$ сукупність інформації характеру стосовно результатів і перспектив діяльності мережевого підприємства. Можливість формування та якісні ознаки інформаційної бази дослідження мережевого підприємства $є$ вагомими чинниками, оскільки доступ до певних джерел інформації обумовлює повноту і достовірність інформації, вибір методів дослідження, коректність. Джерела інформації про діяльність мережевого підприємства класифікують як внутрішні джерела (облікові джерела, бухгалтерська звітність, фінансова звітність, статистична звітність, оперативно-технічна звітність, податкова звітність). Позаоблікові джерела (матеріали ревізій та внутрішнього аудиту; протоколи виробничих нарад, зборів трудових колективів, комісій, засідань правління; накази та розпорядження керівного складу, доповідні та пояснювальні записки; довідники для службового користування; програми, плани, проекти розвитку підприємства; патенти, ліцензії). Зовнішні джерела (відкрита інформація офіційних джерел та засобів масової інформації, звітів, довідників, реклама, Інтернету. Інформація державних та недержавних національних та міжнародних інформаційних служб. Неконфіденційна та конфіденційна інформація, отримана від носія інформації у довірчому порядку). Уся підібрана для діагностики стану мережевого підприємства інформація і, насамперед, показники обліку і звітності, повинна бути ретельно перевірена за формою і змістом. має встановити доброякісність інформації, і лише за цієї умови можна розпочати саму діагностику діяльності підприємств.

Отже, на основі проведеного комплексного аналізу джерел та способів формування інформаційної бази економічного діагностування мережевого підприємства можна проводити цілісну економічну діагностику в сфері інтелектуального бізнесу.

Теорія мережевої економіки досліджує проблеми серед яких моделювання інформаційних ринків , тобто тих, на яких товаром є інформація, інтелектуальна власність, виробництво інтелектуальної продукції, моделювання економічного зростання та ін. [2].

У концепціях постіндустріального суспільства економіка якого грунтується на широкому застосуванні наукового знання, роль творчої особистості та інтелектуальних ресурсів стає провідною. 
Зазначене підтверджується такими характеристиками сучасного способу виробництва: надзвичайно швидкий темп, широкі масштаби та глибина змін у розвитку науки і техніки мають революційний вплив на всю господарську систему, різні галузі матеріального виробництва і сфери послуг, що проявляється у змінах їх співвідношення, структурі зайнятості, технологічних процесів і форм організації виробництва. Для створення суспільного багатства знання та інформація стають вагомішими за матеріальні фактори. Використання цих нових факторів забезпечує зростання ефективності виробництва та збільшення суспільного продукту. У структурі суспільного виробництва збільшується питома вага високотехнологічного сектору, у складі виробленої продукції зростає частка доданої вартості за рахунок інтелектуальної складової, змінюється характер людської праці на користь творчої та інтелектуальної діяльності, разом із процесами дематеріалізації виробництва основним фактором стає рівень технологізації, а основним ресурсом стає творчий та інтелектуальний потенціал працівника.

Слід зазначити, що ще у 90-х роках XX століття японський вчений Т. Сакайя відзначив, «що традиційні фактори виробництва вже не визначають ту цінність, яку споживачі визначають за тим чи іншим продуктом. Зокрема, у 1985 році в книзі «Вартість, створювана знанням, або історія майбутнього» Т. Сакайя писав: «Я вважаю, що нині ми вступаємо в новий етап цивілізації, на якому рушійною силою $\epsilon$ цінності, створювані знаннями, тому я називаю цей етап суспільством, що базується на створюваних знанням цінностях» [3]. Е. Тоффлер у серединні 80-х років ХХ століття зазначив, що більшість компаній «третьої хвилі» вже не збільшують свої прибутки за допомогою «вижимання поту» із своїх співробітників; головного значення набули інформація і творчість [4].

Отже на початку XXI століття була теоретично обгрунтована пріоритетність нематеріальних ресурсів у формуванні конкурентних переваг підприємств. Важливим аспектом використання інформаційних ресурсів $є$ ефект мережевої взаємодії, який обумовлений тим, що багато одиниць сучасної техніки працюють у межах розгалуженої мережі. Чим більше елементів в мережі, тим більше користі і відповідного економічного ефекту.

Мережева економіка має свої специфічні організаційні форми та інститути які є новими або модифікованими. Підприємство є однією 3 організаційних форм, яка добре пристосувалася до гнучкої виробничої системи інформаційної економіки. В дослідженнях італійських підприємств проведених Скіатарелла вказано що «малі та середні фірми краще за великі схильні утворювати робочі місця, отримують прибутки, заохочують інвесторів, збільшують продуктивність»[2].. Фрідман в досліджені японської індустріальної структури вказує, що тільки в густій мережі малих та середніх підприємств субпідрядників міститься японська конкурентоспроможність. Розрахунки М. Тейця при досліджені підприємств Каліфорнії також вказують «на життєву силу та економічну роль малих та середніх підприємств. 3 урахуванням цього можливо сказати що малі та середні фірми представляються формами організації які добре пристосовуються до гнучкої виробничої системи інформаційної економіки» [3]. Спостерігається криза традиційної корпоративної організаційної моделі, заснованої на вертикальній інтеграції та ієрархічнім функціональнім управлінні лінійно-апаратній системою суворого технічного и соціального розділення праці на фірмі.

Малі та середні фірми вводять в життя мультинаправлену мережеву модель. Малі та середні фірми на думку Харрісона «знаходяться під контролем системи субпідрядів або під фінансовотехнологічним господарюванням великих корпорацій». Віктор Сіт встановив що «на початку 1980-х років мережі домашніх фірм забезпечували більше 85\% гонконгського промислового експорту вони не були субпідрядниками великих фірм, але експортували продукцію через мережу малих та середніх експортно-імпортних фірм. Мережі виробництва та розподілу формувалися, зникали та знову формувалися на основі варіацій на світовому ринку, через сигнали, які передавалися посередниками, часто використовували «комерційних шпигунів». Зразком виробничої мережі іншого роду $є$ іспанські середні фірми які мали горизонтальні мережі в інших країнах та галузях» [3]. Виробничі мережі які мають назву модель Бенеттон це муніципальне яке виросло з маленького родинного бізнесу. Це оперує на базі ліцензованих комерційних пільг, має приблизно 5000 магазинів по всьому світі, для ексклюзивного розподілу своєї продукції під контролем центральної фірми. По зворотному зв'язку оnLine центр отримує від всіх пунктів розподілу дані, які вказують на всі необхідні потреби. Мережива модель також ефективна на виробничому рівні, і грунтується на розподілі роботи по невеличких підприємствах та домогосподарствах. Цей тип мереженої організації $є$ проміжною формою між вертикальною дезінтеграцією, через угоди про субпідряд між великою фірмою, і горизонтальною мережею невеличких фірм. Це горизонтальна мережа, але заснована на сукупності відносин «центр периферія», як відносно попиту так і пропозиції. Такі форми горизонтальних ділових мереж, інтегрованих вертикально через фінансовий контроль, характеризують операції прямих продаж в Америці та надають інформацію децентралізованим структурам, багатьох бізнес-консалтингових фірм у Франції, які організовані під «парасолькою» контролю якості.

Кен'ічі Імаі обумовив тезу «про трансформацію корпорацій в мережі досліджуючи японські та американські мультинаціональні корпорації. Він вважає, що процес інтернаціоналізації ділової 
активності проходить в підприємствах трьома стратегічними шляхами. Перший традиційний спосіб відноситься до стратегії ведення операцій на багатьох внутрішніх національних ринках для компаній, які інвестують капітали за кордоном 3 свого національного плацдарму. Друга стратегія націлена на глобальний ринок і організує різні функції компанії в різних країнах, функції, які інтегруються в розробленої глобальній стратегії. Третя стратегія характерна для передової економічної та технологічної стадій, заснованих на мережах, перетинаючи кордони» [4]. При цій стратегії компанії, з одного боку, пов'язані з багатьма внутрішніми національними ринками, з іншої, ці різноманітні ринки обмінюються інформацією між собою. Компанії не контролюють ринки зовні, а інтегрують свої долі ринку та ринкову інформацію, ігноруючи кордони. В старій стратегії прямі іноземні інвестиції націлені на здійснення контролю. А в новій інвестиції націлені на створення мережі відносин між компаніями, які оперують в різному інституційному середовищі. Глобальній конкуренції допомагає «інформація 3 місць» кожного ринку. Основний чинник - інформація, яка поступає з певного місця в певний час. Мережева технологія дозволяє одночасно децентралізувати вилучення такої інформації та інтегрувати її в гнучкої системі розробки стратегії. Ця інтегруюча кордони структура дає можливість невеликім підприємством зв’язуватися з великими корпораціями, формуючи мережі, що дає змогу постійно вводити інновації та здійснювати адаптацію. Таким чином, фактичною оперативною одиницею стає діловий проект, очолюваний мережею, а не окрема компанія чи формальна група компаній. Найбільш важлива інформація в нових економічних умовах, яка оброблюється у процесі обміну між компаніями на основі досвіту, вилученого із кожної області. Інформація циркулює в таких мережах: в мережах між компаніями, в середині компанії, в індивідуальних мережах і в комп'ютерних мережах. Новітні інформаційні технології, по міркуванню Імаі, відіграють вирішальну роль в праці адоптивної моделі. Ця ігноруюча кордони мережива модель є платформою конкурентоспроможності японських фірм [4].

Можливість малих та середніх підприємств зв'язуватися між собою та з великими корпораціями також почала залежить від доступності нових технологій, раз мережі стали глобальними. В Китаї бізнес століттями спирався на мережі довіри та співробітництва. У 1980-х роках мережі потягнулися через кордони і тоді тільки нові комунікації та інформаційні технології дали змогу працювати на постійній основі. Родинні, регіональні, національні кодекси вже встановили базу для правил гри, яких потрібно дотримуватися, але зараз за допомогою комп’ютерів.

\section{Висновки}

3'ясовані напрямки діагностики мережевого підприємства. Визначені принципи діагностування, які полягають в підвалинах мережевого підприємства та за його межам. Системно узагальнено основні напрямки адаптації підприємства інтелектуального бізнесу до глобального простору та його взаємодію 3 іншими суб'єктами інформаційної економіки. Досліджено особливості ринкової модифікації управління мережевими підприємствами та надано ряд практичних рекомендацій щодо підвищення економічної ефективності на всіх рівнях господарювання. Визначено роль діагностування, як джерела підвищення ефективності управління підприємствами на всіх рівнях функціонування в інтелектуальному бізнесі, та особливостей ринкової модифікації управління підприємствами, що можуть бути покладені в основу практичних рекомендацій щодо налагодження їх ефективного функціонування. Діагностування впливає на ефективність діяльності мережевих підприємств і сприяє виходу із системної кризи економіки, в цілому. Запропоновані в досліджені теоретичні підходи до особливостей модифікації управління підприємств інтелектуального бізнесу можуть бути покладені в основу практичних рекомендацій щодо налагодження їх ефективного функціонування в інформаційній економіці

\section{Список використаної літератури}

1.Артемова Т.И. Институт социальной ответственности организации: мировой опыт и реалии Украины / Артемова Т.И. / Наукові праці ДонНТУ. Серія економічна. 2009. Випуск 37-1.Naukovi praci C.170-176.

2. Белова Л.Г. Информационное общество: трансформация экономических отношений в мировой экономике: Монография / Белова Л.Г., Стриженко А.А. / МГУ им. М.В. Ломоносова, АлтГТУ им. И.И. Ползунова. - Барнаул: Изд-во «Азбука», 2007. 387 с.

3. Гриценко А.А. Капитализация экономики в ретроспективе и перспективе / Гриценко А.А. // Методологія, теорія та практика соціологічного аналізу сучасного суспільства. 2009. Вип. 15. С.191-195.

4. Геец В. Социогуманитарные составляющие перспектив перехода к социально ориентированной экономике // Экономика Украины. 2000. №1. С 4-11.

5. Дементьева А. Современные условия глобализации и роль транснациональных корпораций / Дементьева А. // Инициативы XXI века, 2010, №1. С.54-67.

6. Марков М. Современное предпринимательство как кооперация крупных, средних и малых предприятий / Марков М. // Проблемы современной экономики. 2016. №2. С. 15-27.

7. Міжнародні економічні відносини: наочн. навч.-метод. посіб./ А.В. Рибчук, В.М. Фомішиної, С.В. Фомішин; за наук. ред. Рибчук А.В. - 2-ге укр-анг.вид.,перероб., доп.і розшир.- Херсон, Видавничий дім «Гельветика», 2018. 392 с. 


\section{References}

1. Artemova T.I. Institut socialnoi otvetstvennosti organizacii: mirovoi opit i realii Ukraini [Institute of Social Responsibility of the Organization: World Experience and Realities of Ukraine] / T.I. Artemova / Naukovi praci DonNTU. Seriya ekonomichna. 2009. Vipusk 37.1. [Scientific works DonNTU. Seriya is economical. 2009. Issue 37-1]. p.170-176.

2. Belova L.G. Informacionnoe obschestvo: transformaciya ekonomicheskih otnoshenii v mirovoi ekonomike: Monografiya [The Information Society: Transformation of Economic Relations in the World Economy: Monograph] / Belova L.G., Strizhenko A.A. / Moscow State University M.V. Lomonosov Altai State Technical University named after I.I. Polzunova. - Barnaul: Publishing House "ABC", 2007. 387 p.

3. Gritsenko A.A. Kapitalizaciya ekonomiki $v$ retrospektive i perspektive [Capitalization of the economy in retrospect and perspective] / A. Gritsenko // Metodologiya, teoriya ta praktika sociologichnogo analizu suchasnogo suspilstva. [Methodology, theory and practice of sociological analysis of common suspension.] 2009. VIP. 15. p.191-195.

4. Geyets V. Sociogumanitarnie sostavlyayuschie perspektiv perehoda $\mathrm{k}$ socialno orientirovannoi ekonomike // Ekonomika Ukraini [Socio-humanitarian components of the prospects for the transition to a socially oriented economy // Economy of Ukraine.] 2000. No1. p. 4-11.

5. Dementieva A. Sovremennie usloviya globalizacii i rol transnacionalnih korporacii [Modern conditions of globalization and the role of transnational corporations] / Dementieva A. // Iniciativi XXI veka [Initiatives of the XXI century], 2010, No. 1. p.54-67.

6. Markov M. Sovremennoe predprinimatelstvo kak kooperaciya krupnih_srednih i malih predpriyatii [Modern entrepreneurship as a cooperation of large, medium and small enterprises ] / Markov M. // Problemi sovremennoi ekonomiki [Problems of the modern economy]. 2016. №2. p. 15-27.

7. Mijnarodni ekonomichni vidnosini_ naochn. navch._metod. posib.[International economy of business: on the night. vvch.-method. pos.] / A.V.V. Ribchuk, V.M. Fomishina, S.V. Fomishin; for sciences. ed. Ribchuk A.V. - 2-ge ukr-ang.vid.,pererob., dop.i rozshir.- Herson, Vidavnichii dim «Gelvetika» [2-ge ukreng.vid., Reverb., Additional and roshshir. - Kherson, Vidavnichy dim "Helvetika"], 2018. 392 p. 